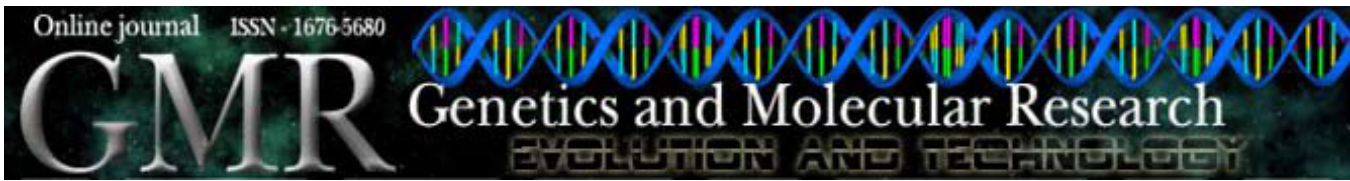

\title{
Association of the PPAR 2 gene Pro12Ala variant with primary hypertension and metabolic lipid disorders in Han Chinese of Inner Mongolia
}

\author{
L. Gao ${ }^{1 *}$, L. Wang ${ }^{2 *}$, H. Yun ${ }^{3}$, L. Su${ }^{1}$ and X. Su${ }^{1}$ \\ ${ }^{1}$ Clinical Research Center of the Affiliated Hospital, \\ Inner Mongolia Medical College, Hohhot, Inner Mongolia, China \\ ${ }^{2}$ The Affiliated People's Hospital of Inner Mongolia Medical College, Hohhot, \\ Inner Mongolia, China \\ ${ }^{3}$ Inner Mongolia International Travel Health Care Center, Hohhot, \\ Inner Mongolia, China \\ *These authors contributed equally to this study. \\ Corresponding author: X. Su \\ E-mail: xlsu@hotmail.com
}

Genet. Mol. Res. 9 (3): 1312-1320 (2010)

Received March 20, 2010

Accepted May 15, 2010

Published July 6, 2010

DOI 10.4238/vol9-3gmr833

\begin{abstract}
In order to determine whether Pro12Ala polymorphism of the peroxisome proliferator-activated receptor $\gamma 2$ (PPAR $\gamma 2)$ gene contributes to susceptibility to primary hypertension and metabolic lipid disorders, 482 unrelated subjects from Inner Mongolia were studied, including 137 healthy normotensive (controls) and 345 hypertensive subjects. PCR-RFLP was used to determine the genotypes of Pro12Ala variants of the PPAR $\gamma 2$ gene, and direct sequencing was used to check the results. The frequency of the Ala allele was lower in patients with hypertension $(1.3 \%)$ than in controls $(3.6 \%)$. The incidence of the Ala allele was significantly lower in patients with hypertension $(\mathrm{P}=0.018)$
\end{abstract}


and in those with elevated blood lipids $(\mathrm{P}=0.040)$, compared to the control group. Total plasma cholesterol, triglycerides and high-density lipoprotein cholesterol were significantly higher $(\mathrm{P}<0.05)$, and lowdensity lipoprotein cholesterol was significantly lower $(\mathrm{P}<0.05)$ in primary hypertension patients than in the control group. We conclude that the Ala allele is involved in genetic susceptibility to hypertension and metabolic lipid disorders in the Han population of Inner Mongolia.

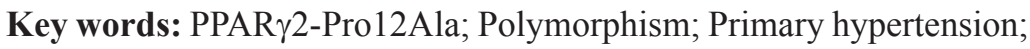
Metabolic lipid disorders; Inner Mongolia

\section{INTRODUCTION}

Hypertension is a multifactorial disorder in which genetic and environmental factors are involved in its pathogenesis. Clinical and experimental studies have indicated that insulin resistance and hyperinsulinemia are important factors contributing to hypertension. Therefore, genetic factors affecting insulin resistance may be involved as a common genetic basis of susceptibility to hypertension.

Peroxisome proliferator-activated receptors (PPARs) are members of the nuclear hormone receptor superfamily of ligand-activated transcription factors that consist of three subtypes (PPAR $\alpha, \beta / \delta$, and $\gamma$ ). PPAR $\gamma$ is a transcription factor that belongs to the same family as the steroid and thyroid hormone receptors (Ahmed et al., 2007). The human PPAR $\gamma$ gene is located on chromosome 3p25 and produces 3 different molecules (PPAR $\gamma 1$, PPAR $\gamma 2$, and PPAR $\gamma 3$ ) by alternative mRNA splicing (Greene et al., 1995). PPAR $\gamma 2$ is specific for adipose tissue, where it plays a key role in regulating adipogenic differentiation. A mutation in the PPAR $\gamma 2$ gene with a cytosine to guanine substitution results in a change of proline (Pro) to alanine (Ala) in exon $\mathrm{B}$ of this gene. Because this mutation is very close to the N-terminal end of the protein, which belongs to the ligand-independent activation domain, it may cause conformational changes and consequently affect its function. The Ala variant has lower affinity for the response element and a lower capacity for activating target genes by about $50 \%$ (Tamori et al., 2002).

It has been shown that PPAR $\gamma$ has an important role in fat generation, lipid metabolism, insulin sensitivity, inflammation, and blood pressure regulation, all of which have drawn great attention in recent years (Vanden Heuvel, 2007; He, 2009). Buzzetti et al. (2005) and Tavares et al. (2005) have shown that PPAR $\gamma$ activation significantly increases insulin sensitivity, ameliorates high blood pressure and dyslipidemia, improves large blood vessel and microvascular lesions in patients with type 2 diabetes, and reduces the risk of cardiovascular disease. Regarding the relationship between the PPAR $\gamma 2$ gene Pro12Ala variants and hypertension, some domestic and international research has drawn different conclusions, especially when different geographic regions and ethnicities are involved. The relationship between the Pro12Ala polymorphism of the PPAR $\gamma 2$ gene in Han Chinese of Inner Mongolia and essential hypertension has not been reported. The subjects we studied are farmers and workers from Hohhot and the surrounding rural area. Their diet consists mostly of grain and meat with less fresh fruits and vegetables. In this study, we clarified the contribution of the Pro12Ala polymorphism of the PPAR $\gamma$ gene to hypertension and blood lipids. The polymorphism was investigated in subjects with hypertension in a genetically homogeneous Inner Mongolia population. 


\section{MATERIAL AND METHODS}

\section{Subjects}

Four hundred and eighty-two unrelated Inner Mongolia subjects were investigated, including 137 normotensive healthy subjects (controls) and 345 hypertensive subjects. Hypertension was diagnosed according to WHO criteria. All subjects gave informed consent. The diagnosis of hypertension was based on systolic blood pressure (SBP) $\geq 140 \mathrm{mmHg}$ and/or a diastolic blood pressure (DBP) $\geq 90 \mathrm{mmHg}$, including those currently and newly diagnosed or having been previously diagnosed and receiving pharmacologic treatment with antihypertensive drugs. Individuals with secondary hypertension, diabetes mellitus, or severe liver and kidney dysfunction were excluded from the study.

According to diagnostic criteria for hyperlipidemia, the hypertensive participants were divided into the following two groups: group $\mathrm{A}(\mathrm{N}=171)$ had hypertension with elevated lipids [total plasma cholesterol (TC) $\geq 5.72 \mathrm{mM}$, and/or triglycerides $(\mathrm{TG}) \geq 1.70 \mathrm{mM}$, and/or low-density lipoprotein cholesterol (LDL-C) $\geq 3.64 \mathrm{mM}$ ], and comprised 121 males and 50 females, with an age range between 20 and 85 years, an average age of $51.77 \pm 13.95$ years, and an average body mass index (BMI) of $25.65 \pm 3.23 \mathrm{~kg} / \mathrm{m}^{2}$; group $\mathrm{B}(\mathrm{N}=174)$ had hypertension without elevated lipids [TG $<1.70 \mathrm{mM}, \mathrm{TC}<5.72 \mathrm{mM}$, and LDL-C $<3.64 \mathrm{mM}$ ], and comprised 130 males and 44 females, with an age range between 22 and 89 years, an average age of $57.12 \pm 17.80$ years, and an average BMI of $14.48 \pm 2.85 \mathrm{~kg} / \mathrm{m}^{2}$. The control group consisted of 137 healthy Han Chinese outpatients from Inner Mongolia who were scheduled for a routine check-up; they were normotensive, and all types of cardiac and cerebrovascular diseases, diabetes, and liver and kidney dysfunction were excluded by medical history, physical examination, laboratory tests, ECG, X-ray, and ultrasound examination. The control group consisted of 79 males and 58 females, with an age range between 20 and 91 years, an average age of $50.08 \pm 15.01$ years, and an average BMI of $23.57 \pm 2.90 \mathrm{~kg} / \mathrm{m}^{2}$. All selected subjects had not taken lipid-lowering drugs for 2 months. The following data were recorded for each subject: name, age, gender, ethnicity, height, weight, and blood pressure (SBP and DBP).

Blood samples were drawn after an overnight fast. TC, TG, HDL-C, and LDL-C were measured according to standardized methods (Beckman Coulter Unicel DxC 800 Synchron Clinical Systems; Beckman Coulter Company, Fullerton, CA, USA).

\section{DNA isolation and PCR-RFLP}

Genomic DNA was isolated from peripheral blood leukocytes using a TIAN amp Blood DNA Kit (TIANGEN Biotech Co., Ltd., Beijing, China). The Pro12Ala polymorphism of the PPAR $\gamma 2$ gene was analyzed using the polymerase chain reaction-restriction fragment length polymorphism (PCR-RFLP) method. The PCR primer sequences were according to the design of Tavares et al. (2005). A segment of the PPAR $\gamma 2$ gene encompassing the Pro12Ala polymorphic site was amplified with the Thermal cycler 2720 PCR amplification apparatus (Applied Biosystems, Foster City, CA, USA) using the sense (5'-CCAATTCAAGCCCAGTCCTTTC-3') and antisense primers (5'-CAGTGAAGGAATCGCTTTCCG-3'). Each PCR was performed in a volume of $25 \mu \mathrm{L}$ containing $2 \mu \mathrm{L}$ genomic DNA, $0.2 \mu \mathrm{L}$ of each primer, $12.5 \mu \mathrm{L} 2 \mathrm{X}$ Taq Master Mix, and $10.1 \mu \mathrm{L}$ sterile double-distilled water. The reaction conditions were as fol- 
lows: initial denaturation step at $95^{\circ} \mathrm{C}$ for $5 \mathrm{~min}$, followed by 35 cycles of denaturation at $94^{\circ} \mathrm{C}$ for $40 \mathrm{~s}$, annealing at $55^{\circ} \mathrm{C}$ for $50 \mathrm{~s}$ and extension at $72^{\circ} \mathrm{C}$ for $1 \mathrm{~min}$, with a final extension of 7 min at $72^{\circ} \mathrm{C}$. Five microliters of PCR products was then digested at $60^{\circ} \mathrm{C}$ for $2 \mathrm{~h}$ with $0.5 \mu \mathrm{L}$ of the restriction endonuclease Bst $\mathrm{U}-\mathrm{I}$ (antisense primers were mismatched in the introduced Ala12 allele Bst $\mathrm{U}-\mathrm{I}$ restriction site and the restriction site was 5'...CG $\rightarrow$ CG...3') using the buffer recommended by the manufacturer (Shanghai Health Industrial Co., Ltd., Shanghai, China). PCR products were analyzed by electrophoresis using a $2 \%$ agarose gel to separate fragments $(100 \mathrm{~V}$ for $1 \mathrm{~h})$. The PCR products after digestion with Bst $\mathrm{U}-\mathrm{I}$ were analyzed by electrophoresis using a $4 \%$ agarose gel to separate fragments $(100 \mathrm{~V}$ for $1 \mathrm{~h})$. The samples were then randomly chosen to separate fragments again by electrophoresis using a $12 \%$ nondenaturing polyacrylamide gel, and the fragments were visualized by means of ethidium bromide Ingot staining, UV strip lamp observation, and photography. Genotype analysis was carried out and the results were recorded. The agarose gel electrophoresis findings were identical to the findings of the $12 \%$ non-denaturing polyacrylamide gel.

\section{Sequencing}

To confirm that the detection of this $\mathrm{C} \rightarrow \mathrm{G}$ nucleotide substitution by PCR-RFLP analysis was reproducible, we also performed PCR-based direct sequencing analysis. The genotype of each study subject was determined blindly without knowledge of clinical status. PP and AA genotypes were selected and re-amplified, and the DNA sequences were verified by direct sequencing (United States ABI Prism 3700 DNA analyzer 377; Applied Biosystems). Genotype frequencies were estimated by direct counting.

\section{Statistical analysis}

Chi-square tests were used to determine whether individual variants were in equilibrium at each locus in the population (Hardy-Weinberg equilibrium). Association of the Pro12Ala variant of the PPAR $\gamma 2$ gene between hypertensive subjects and controls was determined by the chi-square test. Differences between groups of genotypes were tested for significance by a two-tailed test for independent samples. All clinical and biochemical data are reportes as either means $\pm \mathrm{SD}$ or proportion. A P value $<0.05$ was considered to be significant. All data analyses were performed by means of the SPSS 13.0 statistical package.

\section{RESULTS}

The expected DNA fragment of the PPAR $\gamma 2$ gene after PCR amplification was $244 \mathrm{bp}$ (Figure 1A). The expected sizes of the products after digestion with Bst $\mathrm{U}-\mathrm{I}$ for the following 3 genotypes were as follows: homozygous wild-type (Pro/Pro) without a restriction site with an electrophoretic band of $244 \mathrm{bp}$; mutant homozygote (Ala/Ala) with a restriction site in each DNA chain, resulting in electrophoretic bands of 223 and $21 \mathrm{bp}$, and heterozygote (Pro/Ala) with restriction sites in one of the DNA chains, resulting in 3 electrophoretic bands of 244, 223 , and $21 \mathrm{bp}$ (21-bp fragments were not visualized on the gel; Figure 1B). The sequencing results were similar to the digestion results as described previously. Figure $1 \mathrm{C}$ shows the comparison between normal and mutation DNA sequencing of the PPAR $\gamma 2$ gene Pro12Ala 


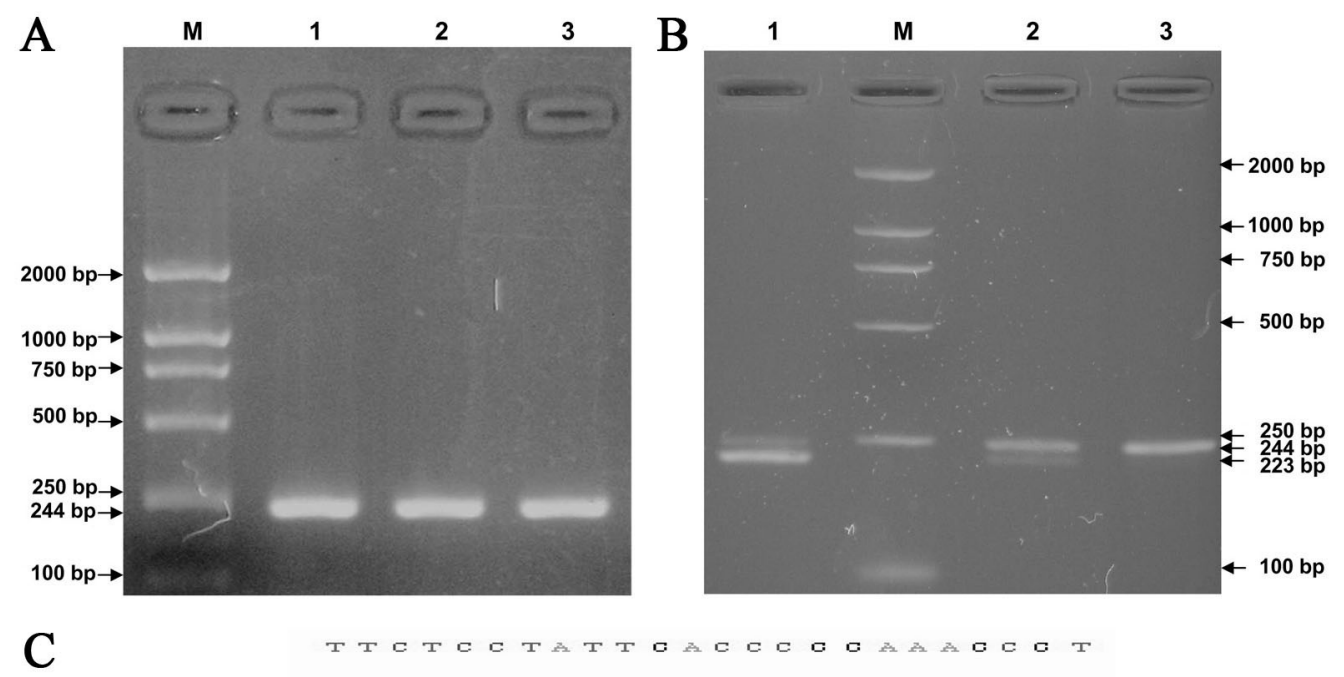

Pro12
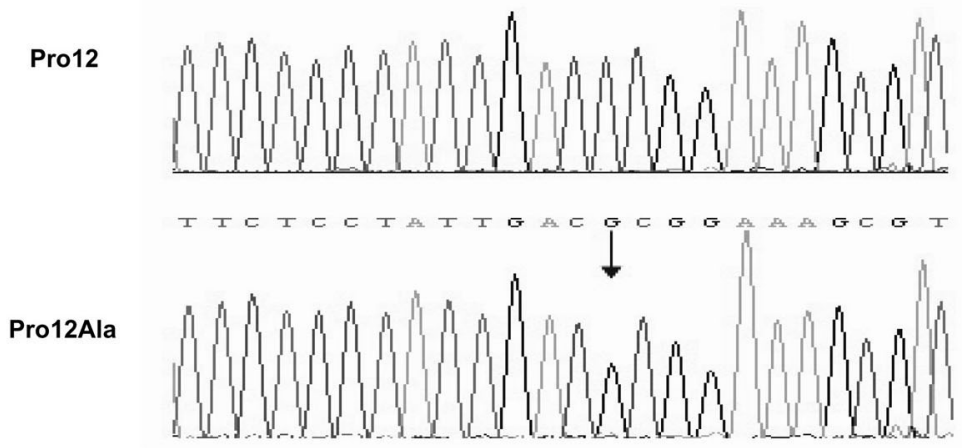

Figure 1. Agarose gel electrophoresis of PCR and PCR-RFLP products, normal and mutation DNA sequencing electropherogram of PPAR $\gamma 2$ gene. A. PCR products were analyzed by electrophoresis using a $2 \%$ agarose gel to separate fragments. $\mathrm{M}=$ Molecular marker; lanes 1, 2, 3 = the expected DNA fragment electrophoresis of the PPAR $\gamma 2$ gene after PCR amplification. B. The PCR products after digestion with $B s t \mathrm{U}-\mathrm{I}$ were analyzed by electrophoresis using a $4 \%$ agarose gel to separate fragments $(100 \mathrm{~V}$ for $1 \mathrm{~h})$. The expected sizes of the products after digestion with $B s t \mathrm{U}-\mathrm{I}$ were for 3 genotypes. $\mathrm{M}=$ Molecular marker; lane 1 =Ala/Ala homozygote; lane 2 = Pro/Ala heterozygote; lane $3=$ Pro/ Pro homozygote. C. DNA sequencing electropherogram of nucleotide substitution C to G (Pro12Ala polymorphism).

polymorphism; it confirmed the nucleotide substitution of C to G.

The PPAR $\gamma 2$ gene Pro/Pro, Pro/Ala, and Ala/Ala genotype frequencies were 97.1, 1.9, and $1.0 \%$, respectively. The Pro allele frequency in our study population was $98.0 \%$ and the Ala allele frequency was $2.0 \%$. When the Hardy-Weinberg equilibrium was evaluated, we observed that the Pro12Ala polymorphism genotype distribution was in accordance with Hardy-Weinberg expectations in the essential hypertension group $\left(\chi^{2}=0.027, \mathrm{P}=0.987\right)$ and in the control group $\left(\chi^{2}=0.079, \mathrm{P}=0.61 ; \mathrm{P}>0.05\right)$. It showed that the study groups were representative.

In this study, we found that the incidence of the Ala allele of PPAR 2 was greater in control subjects than in those with hypertension. Table 1 shows the genotype and the allele frequency distribution of the PPAR $\gamma 2$ gene Pro12Ala polymorphism. There was no significant 
difference between the hypertension and control groups regarding genotype frequency $(\mathrm{P}=$ $0.224)$, but the incidence of Ala allele was significantly different $(P=0.018$; Table 1$)$. There was also no significant difference between those with hypertension with the elevated blood lipid and the control group regarding genotype frequency $(\mathrm{P}=0.315)$, while the Ala allele frequency was significantly different $(\mathrm{P}=0.040$; Table 1$)$. In hypertension without elevated blood lipids, neither genotype frequency nor incidence of Ala allele was significantly different compared to control $(\mathrm{P}=0.302$ and $\mathrm{P}=0.074$, respectively). We showed an association between incidence of allele, hypertension and metabolic lipid disorders.

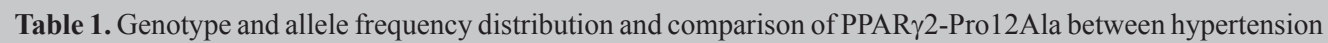
patients (groups A and B) and controls.

\begin{tabular}{|c|c|c|c|c|c|c|c|}
\hline \multirow[t]{2}{*}{ Group } & \multicolumn{3}{|c|}{ Genotype } & \multirow[t]{2}{*}{$\mathrm{P}$} & \multicolumn{2}{|c|}{ Allele frequency } & \multirow[t]{2}{*}{$\mathrm{P}$} \\
\hline & Pro/Pro & Pro/Ala & Ala/Ala & & Pro & Ala & \\
\hline Hypertension & 337 (97.7\%) & $7(2 \%)$ & $1(0.3 \%)$ & 0.244 & $681(98.7 \%)$ & $9(1.3 \%)$ & $0.018 *$ \\
\hline Group A & $167(97.7 \%)$ & $4(2.3 \%)$ & $0(0 \%)$ & 0.315 & $338(98.8 \%)$ & $4(1.2 \%)$ & $0.040 *$ \\
\hline Group B & $170(97.7 \%)$ & $3(1.7 \%)$ & $1(0.6 \%)$ & 0.302 & $343(98.6 \%)$ & $5(1.4 \%)$ & 0.074 \\
\hline Controls & $131(95.6 \%)$ & $2(1.5 \%)$ & $4(2.9 \%)$ & & $264(96.4 \%)$ & $10(3.6 \%)$ & \\
\hline
\end{tabular}

Data are reported as number with percent in parentheses. *Indicates that difference is significant between groups $(\mathrm{P}<0.05)$, based on the Student $t$-test. Group A refers to hypertension with elevated blood lipids. Group B refers to hypertension without elevated blood lipids. Because there were too few of the Ala/Ala homozygous genotype, the Ala/Ala homozygous genotype was combined with the Pro/Ala heterozygous genotype for comparison with the Pro/Pro homozygous genotype in all statistical analyses.

The clinical and metabolic characteristics of the study population $(\mathrm{N}=482)$ are shown in Tables 2 and 3. There was no significant difference between genotype Pro/Pro and Pro/Ala, Ala/Ala regarding age, BMI, and blood pressure and TC, TG, HDL-C, and LDL-C concentrations in both hypertension and control group. TC, TG, HDL-C, and LDL-C were significantly higher $(\mathrm{P}<0.05)$ in hypertension with elevated blood lipids than in hypertension without elevated blood lipids, confirming that our grouping was correct. When the clinical data were compared between the primary hypertension and control groups, we found that TC, TG and HDL-C were significantly higher $(\mathrm{P}<0.05)$ and that LDL-C was much lower $(\mathrm{P}<0.05)$ in primary hypertension than in the control group.

\begin{tabular}{|c|c|c|c|c|c|c|c|c|c|}
\hline \multirow[t]{2}{*}{ Parameter } & \multicolumn{2}{|c|}{ Groups } & \multirow[t]{2}{*}{$\mathrm{P}$} & \multicolumn{2}{|c|}{ Hypertension } & \multirow[t]{2}{*}{$\mathrm{P}$} & \multicolumn{2}{|c|}{ Control } & \multirow[t]{2}{*}{$P$} \\
\hline & $\begin{array}{l}\text { Hypertension } \\
(\mathrm{N}=345)\end{array}$ & $\begin{array}{c}\text { Control } \\
(\mathrm{N}=137)\end{array}$ & & $\begin{array}{c}\mathrm{PP} \\
(\mathrm{N}=337)\end{array}$ & $\begin{array}{l}\mathrm{PA} / \mathrm{AA} \\
(\mathrm{N}=8)\end{array}$ & & $\begin{array}{c}\text { PP } \\
(\mathrm{N}=131)\end{array}$ & $\begin{array}{l}\mathrm{PA} / \mathrm{AA} \\
(\mathrm{N}=6)\end{array}$ & \\
\hline Men/women & $251 / 94$ & $79 / 58$ & $0.001 *$ & & & & & & \\
\hline Age (years) & $54.47 \pm 16.21$ & $50.08 \pm 15.01$ & $0.005^{*}$ & $54.42 \pm 16.12$ & $56.25 \pm 20.55$ & 0.753 & $49.92 \pm 14.75$ & $53.67 \pm 21.46$ & 0.551 \\
\hline BMI $\left(\mathrm{kg} / \mathrm{m}^{2}\right)$ & $25.06 \pm 3.09$ & $23.57 \pm 2.90$ & $0.000 *$ & $25.05 \pm 3.09$ & $25.31 \pm 2.85$ & 0.818 & $23.61 \pm 2.86$ & $22.69 \pm 3.89$ & 0.451 \\
\hline $\mathrm{SBP}(\mathrm{mmHg})$ & $147.82 \pm 15.48$ & $119.93 \pm 11.09$ & $0.000 *$ & $147.75 \pm 15.35$ & $150.75 \pm 21.27$ & 0.704 & $111.91 \pm 11.00$ & $120.5 \pm 14.45$ & 0.899 \\
\hline DBP (mmHg) & $88.09 \pm 11.19$ & $73.26 \pm 9.11$ & $0.000 *$ & $88.09 \pm 11.21$ & $88.25 \pm 11.08$ & 0.967 & $73.33 \pm 9.09$ & $71.67 \pm 10.13$ & 0.664 \\
\hline $\mathrm{TG}(\mathrm{mM})$ & $1.91 \pm 1.45$ & $1.63 \pm 1.18$ & $0.043^{*}$ & $1.90 \pm 1.44$ & $2.44 \pm 2.04$ & 0.294 & $1.63 \pm 1.18$ & $1.47 \pm 1.17$ & 0.739 \\
\hline $\mathrm{TC}(\mathrm{mM})$ & $4.93 \pm 0.90$ & $4.75 \pm 0.85$ & $0.025^{*}$ & $4.93 \pm 0.89$ & $5.18 \pm 1.24$ & 0.440 & $4.73 \pm 0.84$ & $5.13 \pm 1.66$ & 0.266 \\
\hline HDL-C (mM) & $3.07 \pm 0.80$ & $2.79 \pm 0.64$ & $0.001 *$ & $3.07 \pm 0.80$ & $2.80 \pm 0.84$ & 0.340 & $2.79 \pm 0.63$ & $2.93 \pm 0.81$ & 0.588 \\
\hline LDL-C (mM) & $1.26 \pm 0.37$ & $1.40 \pm 0.44$ & $0.000 *$ & $1.26 \pm 0.37$ & $1.22 \pm 0.47$ & 0.789 & $1.39 \pm 0.45$ & $1.52 \pm 0.35$ & 0.501 \\
\hline
\end{tabular}

Data are reported as means $\pm \mathrm{SD}$. *Indicates that difference is significant between groups $(\mathrm{P}<0.05)$. $\mathrm{BMI}=$ body mass index; $\mathrm{SBP}=$ systolic blood pressure; $\mathrm{DBP}=$ diastolic blood pressure; $\mathrm{TG}=$ triglycerides; $\mathrm{TC}=$ total cholesterol; HDL-C and LDL-C = high- and low-density lipoprotein cholesterol, respectively. 
Table 3. Biochemical and anthropometric parameters of hypertension patients with (group A) and without (group B) elevated blood lipids according to group and PPAR 2 2-Pro12Ala genotype.

\begin{tabular}{|c|c|c|c|c|c|c|c|c|c|}
\hline \multirow[t]{2}{*}{ Parameter } & \multicolumn{2}{|c|}{ Hypertension group } & \multirow[t]{2}{*}{$P$} & \multicolumn{2}{|c|}{ Group A } & \multirow[t]{2}{*}{$P$} & \multicolumn{2}{|c|}{ Group B } & \multirow[t]{2}{*}{$\mathrm{P}$} \\
\hline & $\begin{array}{c}\text { Group A } \\
(\mathrm{N}=171)\end{array}$ & $\begin{array}{c}\text { Group B } \\
(\mathrm{N}=174)\end{array}$ & & $\begin{array}{c}\mathrm{PP} \\
(\mathrm{N}=167)\end{array}$ & $\begin{array}{l}\mathrm{PA} / \mathrm{AA} \\
(\mathrm{N}=4)\end{array}$ & & $\begin{array}{c}\mathrm{PP} \\
(\mathrm{N}=170)\end{array}$ & $\begin{array}{l}\text { PA/AA } \\
(\mathrm{N}=4)\end{array}$ & \\
\hline Men/women & $121 / 50$ & $130 / 44$ & 0.410 & & & & & & \\
\hline Age (years) & $51.77 \pm 13.95$ & $57.12 \pm 17.80$ & $0.002^{*}$ & $51.65 \pm 13.67$ & $56.75 \pm 25.59$ & 0.717 & $57.15 \pm 17.84$ & $55.75 \pm 18.15$ & 0.877 \\
\hline BMI $\left(\mathrm{kg} / \mathrm{m}^{2}\right)$ & $25.65 \pm 3.23$ & $24.48 \pm 2.85$ & $0.000^{*}$ & $25.63 \pm 3.21$ & $26.57 \pm 4.50$ & 0.568 & $24.49 \pm 2.88$ & $24.06 \pm 0.99$ & 0.763 \\
\hline $\mathrm{SBP}(\mathrm{mmHg})$ & $147.53 \pm 15.67$ & $148.11 \pm 15.33$ & 0.730 & $147.52 \pm 15.60$ & $148.00 \pm 21.04$ & 0.952 & $147.98 \pm 15.14$ & $153.50 \pm 24.34$ & 0.682 \\
\hline $\mathrm{DBP}(\mathrm{mmHg})$ & $89.85 \pm 11.18$ & $86.36 \pm 10.96$ & $0.004^{*}$ & $88.98 \pm 11.15$ & $84.50 \pm 12.37$ & 0.334 & $86.22 \pm 10.98$ & $92.00 \pm 9.80$ & 0.299 \\
\hline $\mathrm{TG}(\mathrm{mM})$ & $2.85 \pm 1.55$ & $0.99 \pm 0.32$ & $0.000^{*}$ & $2.83 \pm 1.53$ & $3.72 \pm 2.32$ & 0.257 & $0.98 \pm 0.33$ & $1.17 \pm 0.19$ & 0.266 \\
\hline $\mathrm{TC}(\mathrm{mM})$ & $5.31 \pm 0.96$ & $4.57 \pm 0.65$ & $0.000^{*}$ & $5.30 \pm 0.95$ & $5.46 \pm 1.75$ & 0.866 & $4.56 \pm 0.65$ & $4.89 \pm 0.54$ & 0.319 \\
\hline HDL-C (mM) & $3.22 \pm 0.92$ & $2.91 \pm 0.61$ & $0.000^{*}$ & $3.24 \pm 0.92$ & $2.61 \pm 1.22$ & 0.183 & $2.91 \pm 0.62$ & $2.99 \pm 0.22$ & 0.808 \\
\hline LDL-C (mM) & $1.21 \pm 0.44$ & $1.30 \pm 0.29$ & $0.024^{*}$ & $1.22 \pm 0.44$ & $0.92 \pm 0.33$ & 0.181 & $1.30 \pm 0.29$ & $1.52 \pm 0.40$ & 0.128 \\
\hline
\end{tabular}

Data are reported as means $\pm \mathrm{SD}$. *Indicates that difference is significant between groups $(\mathrm{P}<0.05)$. BMI $=$ body mass index; $\mathrm{SBP}=$ systolic blood pressure; $\mathrm{DBP}=$ diastolic blood pressure; $\mathrm{TG}=$ triglycerides; $\mathrm{TC}=$ total cholesterol; HDL-C and LDL-C = high- and low-density lipoprotein cholesterol, respectively.

\section{DISCUSSION}

In our case-control study, the Ala phenotype frequency was low both in control and hypertension groups and the Ala allele frequency was significantly different $(P=0.018)$, suggesting the contribution of the Pro12Ala polymorphism of the PPAR $\gamma 2$ gene to susceptibility to hypertension. Our results are in agreement with others' findings (Horiki et al., 2004), and it is plausible that these differences in findings can be attributed to the selection of study populations. The control and hypertension groups differed significantly with regard to characteristics, including age, BMI, blood pressure, TG, TC, HDL-C, and LDL-C. There was no significant association between the Pro12Ala polymorphism and the clinical and metabolic characteristics.

Regarding the association of the polymorphism with hypertension, controversial data have been published. Some group (Rodriguez-Esparragon et al., 2003; Yliharsila et al., 2004; Sookoian et al., 2005) found that the Pro12Ala variant was significantly associated with hypertension. While, Gouni-Berthold et al. (2005) considered that there was no significant correlation between the Pro12Ala variant and blood pressure. Douglas et al. (2001) found that the Pro12Ala variant group had a higher DBP in grossly obese (BMI $>40 \mathrm{~kg} / \mathrm{m}^{2}$ ) diabetic subjects, while in non-diabetic spouses, the Pro12Ala variant was associated with higher SBP and DBP. Stefanski et al. (2006) reported that the DBP of people carrying the PA genotype was higher than with the PP genotype. Ostgren et al. (2003) reported that the Pro12Ala mutation was significantly associated with low DBP. All these controversial results may be due to differences in race, aims, sample size, observed variables, methods, and environmental factors.

Regarding the relationship between the PPAR $\gamma 2$ gene Pro12Ala polymorphism and blood lipids, the conclusions were also controversial (Douglas et al., 2001; Hasstedt et al., 2001; Ereqat et al., 2009; Mirzaei et al., 2009). We found that Ala allele frequencies were significantly different between those with hypertension with elevated blood lipids $(\mathrm{P}=0.040)$ and the control group. However, further analysis did not reveal a significant difference between the Pro12Ala variant and TC, TG, HDL-C, and LDL-C in the hypertension group. Our results are consistent with previous studies (Swarbrick et al., 2001; Zietz et al., 2002; Pinterova et al., 2004; Tai et al., 2004), and reveal a role of this variant in dyslipidemia risk.

In conclusion, our study shows that the Ala allele is involved in the genetic suscep- 
tibility to hypertension in an Inner Mongolia population and that the incidence of the Ala allele is significantly different between those with hypertension with elevated blood lipids ( $\mathrm{P}$ $=0.040$ ) and the control group, suggesting that the PPAR $\gamma 2$ gene Pro12Ala variant may be associated with dyslipidemia risk. Indentifying the PPAR $\gamma 2$ Pro12Ala polymorphism based on clinical observation will give clues to determine the molecular mechanism by which the alteration of the PPAR $\gamma 2$ activity mediates hypertension, which may in turn facilitate a more effective strategy for the management of hypertension.

\section{ACKNOWLEDGMENTS}

Research supported by grants from the ChunHui Plan from the Ministry of Education and the Hohhot Technology Bureau of Inner Mongolia. We are grateful for samples provided by the Inner Mongolia International Travel Health Care Center.

\section{REFERENCES}

Ahmed W, Ziouzenkova O, Brown J, Devchand P, et al. (2007). PPARs and their metabolic modulation: new mechanisms for transcriptional regulation? J. Intern. Med. 262: 184-198.

Buzzetti R, Petrone A, Caiazzo AM, Alemanno I, et al. (2005). PPAR-gamma2 Pro12Ala variant is associated with greater insulin sensitivity in childhood obesity. Pediatr. Res. 57: 138-140.

Douglas JA, Erdos MR, Watanabe RM, Braun A, et al. (2001). The peroxisome proliferator-activated receptor-gamma2 Pro12A1a variant: association with type 2 diabetes and trait differences. Diabetes 50: 886-890.

Ereqat S, Nasereddin A, Azmi K, Abdeen Z, et al. (2009). Impact of the Pro12Ala polymorphism of the PPAR-gamma 2 gene on metabolic and clinical characteristics in the Palestinian type 2 diabetic patients. PPAR Res. 2009: 874126.

Gouni-Berthold I, Giannakidou E, Muller-Wieland D, Faust M, et al. (2005). Peroxisome proliferator-activated receptorgamma2 Pro12Ala and endothelial nitric oxide synthase-4a/b gene polymorphisms are not associated with hypertension in diabetes mellitus type 2. J. Hypertens. 23: 301-308.

Greene ME, Blumberg B, McBride OW, Yi HF, et al. (1995). Isolation of the human peroxisome proliferator activated receptor gamma cDNA: expression in hematopoietic cells and chromosomal mapping. Gene Expr. 4: 281-299.

Hasstedt SJ, Ren QF, Teng K and Elbein SC (2001). Effect of the peroxisome proliferator-activated receptor-gamma 2 pro(12)ala variant on obesity, glucose homeostasis, and blood pressure in members of familial type 2 diabetic kindreds. J. Clin. Endocrinol. Metab. 86: 536-541.

He W (2009). PPARgamma2 polymorphism and human health. PPAR. Res. 2009: 849538.

Horiki M, Ikegami H, Fujisawa T, Kawabata Y, et al. (2004). Association of Pro12Ala polymorphism of PPARgamma gene with insulin resistance and related diseases. Diabetes Res. Clin. Pract. 66 (Suppl 1): S63-S67.

Mirzaei H, Akrami SM, Golmohammadi T, Doosti M, et al. (2009). Polymorphism of Pro12Ala in the peroxisome proliferator-activated receptor gamma2 gene in Iranian diabetic and obese subjects. Metab. Syndr. Relat. Disord. 7: 453-458.

Ostgren CJ, Lindblad U, Melander O, Melander A, et al. (2003). Peroxisome proliferator-activated receptorgammaPro12Ala polymorphism and the association with blood pressure in type 2 diabetes: Skaraborg Hypertension and Diabetes Project. J. Hypertens. 21: 1657-1662.

Pinterova D, Cerna M, Kolostova K, Novota P, et al. (2004). The frequency of alleles of the Pro12Ala polymorphism in PPARgamma2 is different between healthy controls and patients with type 2 diabetes. Folia Biol. 50: 153-156.

Rodriguez-Esparragon FJ, Rodriguez-Perez JC, Macias-Reyes A and Alamo-Santana F (2003). Peroxisome proliferatoractivated receptor-gamma2-Pro12Ala and endothelial nitric oxide synthase-4a/bgene polymorphisms are associated with essential hypertension. J. Hypertens. 21: 1649-1655.

Sookoian S, Garcia SI, Porto PI, Dieuzeide G, et al. (2005). Peroxisome proliferator-activated receptor gamma and its coactivator-1 alpha may be associated with features of the metabolic syndrome in adolescents. J. Mol. Endocrinol. 35: 373-380.

Stefanski A, Majkowska L, Ciechanowicz A, Frankow M, et al. (2006). Association between the Pro12Ala variant of the peroxisome proliferator-activated receptor-gamma2 gene and increased 24-h diastolic blood pressure in obese patients with type II diabetes. J. Hum. Hypertens. 20: 684-692. 
Swarbrick MM, Chapman CM, McQuillan BM, Hung J, et al. (2001). A Pro12Ala polymorphism in the human peroxisome proliferator-activated receptor-gamma 2 is associated with combined hyperlipidaemia in obesity. Eur. J. Endocrinol. 144: $277-282$.

Tai ES, Corella D, Deurenberg-Yap M, Adiconis X, et al. (2004). Differential effects of the C1431T and Pro12Ala PPARgamma gene variants on plasma lipids and diabetes risk in an Asian population. J. Lipid Res. 45: 674-685.

Tamori Y, Masugi J, Nishino N and Kasuga M (2002). Role of peroxisome proliferator-activated receptor-gamma in maintenance of the characteristics of mature 3T3-L1 adipocytes. Diabetes 51: 2045-2055.

Tavares V, Hirata RD, Rodrigues AC, Monte O, et al. (2005). Association between Pro12Ala polymorphism of the PPARgamma2 gene and insulin sensitivity in Brazilian patients with type-2 diabetes mellitus. Diabetes Obes. Metab. 7 : 605-611.

Vanden Heuvel JP (2007). The PPAR resource page. Biochim. Biophys. Acta 1771: 1108-1112.

Yliharsila H, Eriksson JG, Forsen T, Laakso M, et al. (2004). Interactions between peroxisome proliferator-activated receptor-gamma 2 gene polymorphisms and size at birth on blood pressure and the use of antihypertensive medication. J. Hypertens. 22: 1283-1287.

Zietz B, Barth N, Spiegel D, Schmitz G, et al. (2002). Pro12Ala polymorphism in the peroxisome proliferator-activated receptor-gamma2 (PPARgamma2) is associated with higher levels of total cholesterol and LDL-cholesterol in male Caucasian type 2 diabetes patients. Exp. Clin. Endocrinol. Diabetes 110: 60-66. 